DOI: 10.1515/auseur-2016-0026

\title{
Festivals in Transylvania
}

A Review of the Volume

\section{Barna Bodó (ed.): Hungarian Civil Yearbook of Transylvania $2015^{1}$}

\author{
Dénes KISS \\ Babeş-Bolyai University, Cluj-Napoca \\ kissdenes2000@yahoo.com
}

The term Yearbook in the title of the book is slightly misleading because while yearbooks usually contain a collection of thematically diverse studies, in this case we are faced with a thematically strict, specific phenomenon: town and village festivals, celebratory events.

This volume focussed the attention on events which have become widespread in the past quarter of a century - this spread is indicated by the book as a whole, but especially the database at the end of the book, in which we can find information about 486 such events (the number of events is probably higher in reality because this result applies only to events that are available via Internet information).

The book consists of three chapters and an introductory study. The first chapter (Days, Festivals, Events - Case Studies) consists of studies about festivals. The book includes altogether eighteen 5-10-page case studies, whose primary aim is to describe and present the festivals, but some of the authors, besides giving a description, also try to interpret and analyse those cases (in this sense, I would like to highlight the study case of Andrea Sólyom from Székelyudvarhely/ Odorheiu Secuiesc). In the second chapter (Days, Festivals, Events in the Press), we may read about 17 additional festivals, but those do not exceed the selection and presentation of sources available on the Internet. Nevertheless, the third chapter (The Register of Days, Festivals, and Events) contains all the registers of festivals which can be found on Internet, split into urban and rural categories.

The introductory study of the volume, whose title is The Steps of Occupancy, is actually the most important part of the volume, in which the author - the editor of the volume -, after introducing the topic, does the analysis of the whole book.

1 Barna Bodó (ed.), Erdélyi Magyar Civil Évkönyv 2015. Erdélyi Múzeum Egyesület, Cluj-Napoca, 2016. 
On the one hand, he outlines the story of the festivals existing today, splitting it into five eras based on the time when the respective festivals took shape.

a) The beginnings of a part of these festivals reach back before 1989 - typically, precursors of them being of religious and folk nature (country fairs, carnivals). Nowadays' festivals constitute a relatively little proportion of these.

b) The first town festivals, among which there were several ones related to the Hungarian population, were organized in the period of 1990-96. These town festivals had no precedent in Romania, and therefore can be considered as innovation.

c) In the period of 1997-2000, in an already changed political atmosphere, the number of the programmes slowly started to grow.

d) Between 2000 and 2008, there follows the period of a sudden increase. In these years - which are at the same time the years of the economic upheaval -, before the accession to the European Union, the programmes counting as innovations earlier became universally widespread. All locations which count and all Hungarian communities try to organize their own days, festivals.

e) This sudden increase slows down after 2008, the programmes become regular, and the number of festivals no longer increases.

The above process can be recognized in the distribution of festivals among villages and towns. While in the beginning we are facing an urban phenomenon, by today, village programmes have numerically exceeded city programmes. In this sense, the exceptions are the fragmented parts, the internal diaspora - for example, Banat -, where most of the rural, fragmented communities are too small to organize such programmes; here, the urban festivals are in predominance.

In the process of becoming universal types of festival organizing, there are some really important, successful programmes playing the role of examples for others, such as Szentgyörgy Napok/St George Days or Kolozsvári Magyar Napok/ Hungarian Days of Cluj-Napoca, while possibly the most important thing is that as a result of becoming large-scale events, they produce and accumulate a festivalorganizing knowledge base, which leads to the development of the festival industry. Another result of the increased number and popularity of festivals is their becoming the object of political competition; at least in internal diaspora, these have become the explicit part of the political programme of the RMDSZ/ DAHR, which makes available and permanently secures the completion of the funds and sources needed for the organization of these events.

As part of the festival history, the book gives an elaborated idea of the types of festival-like programmes. The type systematization directs our attention to the most important features of the programmes and, at the same, indicates the possible explanations of differences. One aspect which helps determining the type of a festival is related to its organizers: whether these are representatives of the local government or civilians. 
Usually, the local governments are the key characters of the festival organizations, but this is mostly in the Hungarian-majority territories. A general pattern seems to arise: the less the number of Hungarians is in a settlement (that is, the more they are in minority), the more civilians tend to become the main organizers of such festivals. The seemingly clear picture is complicated by the fact that in the majority of the situations the widespread form is the tight cooperation with civil organizations - civil participation depends on the cooperation policy of the local governments and the civil society.

Another aspect is the open or closed character of the programmes, which means that the venues of the programmes are either open-air or indoor places such as community centres or church buildings. In this sense, the position taken by the minority appears to be determinant. The more a Hungarian community is a local minority, the more it aims for organizing a closed programme.

The third viewpoint of type creation is the politically charged or apolitical approach of these programmes or the extent to which a certain festival aims at minority promotion or how much it is a counter-reaction for previous antiminority public space politics. It is well known that the 80s' and the first part of the 90s' anti-minority politics were connected to the symbolism of the public space. At that time, a systematic endeavour was taking place, where the symbolic presence of the minorities in public spaces was suppressed. After the political transformation, from the very beginning, minority endeavours could be interpreted as part of this symbolical territory occupation fight. The endeavours of the Hungarian minority, ever since the first moment of the regime change, can be interpreted as part of their struggle for symbolic space. In the 1990s, the occupation of symbolic space was characterized mainly by erecting new statues and placing memorial tablets; later, however, this was replaced with or completed by festival organization.

In the understanding of the different manners of the festival organization, the key factor is the fragmented character of the Hungarian communities. Different organizational methods and techniques are typical where Hungarians form a local majority (Szeklerland), while on the other end there are Hungarians living in local minority (in Banat, South Transylvania, etc.). We can also encounter specific cases in ethnically balanced communities, where the symbolic presence in public places is the subject of conflicts - as the case study on Marosvásárhely/ Târgu-Mureş presents it in details.

The book, primarily in the introductory study, approaches a lot of interesting topics related to the phenomenon of festivals. One such topic is the construction of self-image, which might cover a number of different issues, as a festival, while constructing its own image, can make attempts to fashion the image of the settlement itself, to build and change the brand of that settlement, but it can also target only and exclusively the Hungarian community in the given settlement. 
The case studies would have made possible the examination of additional topics, but the interpretative study of the volume unfortunately does not deal with it. In this sense, even if quite latent, but in some case studies we can meet the elitist endeavour of the festivals. In the contrast between the junk, the 'grilled minced meat rolls' and the beer festivals, and the high-standard cultural programmes, the conflict of the elite culture with mass culture is highlighted, questioning which social class, strata festivals should be addressed. Furthermore, besides the ethnical exclusion or the dilemma of the dialogue, there appears the question of the Romany population, rather with a social character; however, the volume has yet to touch upon this issue. 